\title{
Bioassay of two Leguminous Plants: Enterolobium saman Prain and Albizzia lebbek Benth.
}

\author{
M. Kaisarul Islam¹, Asma Rahman², Md. S. Hossain ${ }^{3}$ and A. J abbar ${ }^{1}$ \\ ${ }^{1}$ Department of Pharmaceutical Chemistry, Faculty of Pharmacy, University of Dhaka, Dhaka-1000, Bangladesh \\ ${ }^{2}$ Drug Analysis \& Research Laboratory, Centre for Advanced Research in Sciences, University of Dhaka, \\ Dhaka-1000, Bangladesh \\ ${ }^{3}$ Bioassay Section, Analytical Research Division, BCSIR, Dhaka-1205, Bangladesh
}

The biological activities of Enterolobium saman Prain and Albizzia lebbek Benth, two species of Leguminosae family were investigated. The fruits of E. saman were extracted with methanol and the extract was subjected to acid-base treatment for the isolation of alkaloid. The stem bark of A. lebbek was also extracted with methanol and the extract was fractionated by using standard chromatographic techniques. The crude methanol extract and corresponding fractions were investigated for their antimicrobial and cytotoxic activities. The crude methanol extract of E. saman and caffeine (1) isolated from it were found to produce zone of inhibition of 8 to $25 \mathrm{~mm}$ and 10 to $27 \mathrm{~mm}$, respectively. The crude methanol extract and mixed fractions (F-34 and 35) of A. lebbek produced zone of inhibition between 8 to $14 \mathrm{~mm}$ and 8 to $10 \mathrm{~mm}$ against the bacterial strains and 10 to $14 \mathrm{~mm}$ and 09 $\mathrm{mm}$ against fungal strains at $500 \mu \mathrm{g} / \mathrm{disc}$ and 250 $\mu \mathrm{g} /$ disc respectively. All samples were also screened for cytotoxic activities by using brine shrimp lethality bioassay. $\mathrm{LC}_{50}$ (lethal dose concentration at $50 \%$ mortality) for crude methanol extract and residue of E. saman were found to be 1.56 and $0.781 \mu \mathrm{g} / \mathrm{mL}$, while A. lebbek showed $\mathrm{LC}_{50}$ of 3.125 and 1.563 $\mu \mathrm{g} / \mathrm{mL}$ for crude methanol extract and mixed fractions (F-34 and 35), respectively. $\mathrm{LC}_{90}$ values were also observed to get an idea about the toxic concentration of extractives.

Correspondence to: $\mathrm{M}$. Kaisarul Islam

Email:m_kislam@yahoo.com

Dhaka Univ. J. Pharm. Sci. 10(2): 143-146, 2011 (December)
E. saman (Jacq.) Prain (Family-Leguminosae, subfamily- Mimosoideae) is a large tree available in Bangladesh with the Bengali name of "Koroi"." The fresh leaves of the plants are used in diarrhea. ${ }^{1}$ Previous investigations with $E$. saman have revealed the presence of a number of secondary metabolites including triterpene, enterolosaponins $\mathrm{A}$ and $\mathrm{B}^{2}$, and albizzine..$^{3-5}$ A. lebbeck is a moderate to large tree that reaches $30 \mathrm{~m}$ in height in rain forests. It is a fodder tree in the tropic and sub-tropic region. ${ }^{6}$ The bark is used locally in India for tanning fishing nets, treating boils, as soap, anthelmintic, anti-inflammatory and in treatment of bronchitis, toothache and leprosy, ${ }^{7,8}$ while the leaves and seeds were used for eye problem. ${ }^{9}$ Previous phytochemical studies with A. lebbek led to the isolation of glycosides, ${ }^{10}$ terpenoids, steroids, saponins, ${ }^{11}$ anthraquinones and other phenolics, ${ }^{12}$ volatile oils, ${ }^{13}$ tannins, ${ }^{14}$ gums, ${ }^{15}$ and lipoidal matter. ${ }^{16}$

The fruit sample of E. saman and stem bark of A. lebbek were collected from the campus of the University of Dhaka, Dhaka-1000, Bangladesh in December 2005. The plants were properly identified and a voucher specimen has been deposited in the Bangladesh National Herbarium $(\mathrm{BNH})$ under the accession number, DACB-32081 and DACB-32758, respectively.

The fruits of E. saman and stem bark of $A$. lebbek were cut into pieces, sun-dried for about 7 days and then ground to coarse powder. The coarse powdered samples were then stored in airtight container. The powdered fruits of E. saman and stem 
bark of $A$. lebbek were cold extracted with methanol ${ }^{17}$ at room temperature. The extract of fruits of $E$. saman was subjected to acid-base treatment for separation of the alkaloids. The xanthine alkaloid caffeine (1) ${ }^{18}$ and also $p$-anisaldehyde (2) ${ }^{19-21}$ were isolated from the column fractions of the 'alkaloid containing residue' by elution with ethyl acetatemethanol (90:10) and ethyl acetate-methanol (50:50), respectively.<smiles>Cn1c(=O)c2c(ncn2C)n(C)c1=O</smiles>

Caffeine (1)<smiles>COc1ccc(C=O)cc1</smiles>

p-Anisaldehyde (2)

Table 1. Antimicrobial activity of $\boldsymbol{E}$. saman extractives

\begin{tabular}{|c|c|c|c|}
\hline \multirow{2}{*}{ Test microorganism } & \multicolumn{3}{|c|}{ Diameter of zone of inhibition (mm) } \\
\hline & $\mathrm{ME}$ & $\mathrm{C}-1$ & KAN \\
\hline \multicolumn{4}{|l|}{ Gram Positive } \\
\hline Bacillus cereus (BTCC-19) & 20 & 25 & 50 \\
\hline B. megaterium (BTCC-18) & 22 & 27 & 46 \\
\hline B. subtilis & 22 & 25 & 30 \\
\hline Staphylococcus aureus (BTCC-43) & 12 & 10 & 46 \\
\hline \multicolumn{4}{|l|}{ Gram Negative } \\
\hline Escherichia coli (BTCC-172) & 25 & - & 35 \\
\hline Salmonella typhi & 08 & 21 & 38 \\
\hline Sa. paratyphi & 09 & 20 & 35 \\
\hline \multicolumn{4}{|l|}{ Fungi } \\
\hline Saccharromyces cevevaceae & - & - & 38 \\
\hline Candida albicans & 22 & 20 & 40 \\
\hline Aspergillus niger & - & - & 38 \\
\hline
\end{tabular}

ME: methanol extract; C-1: caffeine; KAN: standard kanamycin disc; diameter of zone of inhibition less than 7 mm was considered inactive (-)

Table 2. Antimicrobial activity study A. lebbek extractives

\begin{tabular}{|c|c|c|c|}
\hline \multirow[b]{2}{*}{ Test microorganism } & \multicolumn{3}{|c|}{ Diameter of zone of inhibition (mm) } \\
\hline & $\begin{array}{c}\mathrm{ME} \\
(500 \mu \mathrm{g} / \mathrm{disc})\end{array}$ & $\begin{array}{c}\mathrm{F}-34,35 \\
(250 \mu \mathrm{g} / \mathrm{disc})\end{array}$ & $\begin{array}{c}\text { KAN } \\
(30 \mu \mathrm{g} / \text { disc })\end{array}$ \\
\hline \multicolumn{4}{|l|}{ Gram Positive } \\
\hline Bacillus cereus (BTCC-19) & 10 & 09 & 50 \\
\hline B. megaterium (BTCC-18) & 10 & 10 & 46 \\
\hline B. subtilis & 09 & 08 & 30 \\
\hline Staphylococcus aureus (BTCC-43) & 10 & 10 & 46 \\
\hline Sarcina lutea & 09 & 10 & 35 \\
\hline \multicolumn{4}{|l|}{ Gram Negative } \\
\hline Pseudomonas aeruginosa & 08 & 10 & 40 \\
\hline Salmonella paratyphi & 09 & 09 & 35 \\
\hline Salmonella typhi & 14 & 10 & 38 \\
\hline Shigella boydii & 10 & 10 & 40 \\
\hline Sh. dysenteriae & - & 10 & 35 \\
\hline Vibrio mimicus & 10 & - & 40 \\
\hline$V \cdot$ parahemolyticus & 14 & 09 & 40 \\
\hline \multicolumn{4}{|l|}{ Fungi } \\
\hline Saccharromyces cevevaceae & 14 & 09 & 38 \\
\hline Aspergillus niger & 10 & 09 & 38 \\
\hline
\end{tabular}

ME: methanol extract; F-34, 35: Mixed Fraction 
The preliminary antimicrobial activity of the crude methanol extract and caffeine (1) from $E$. saman was determined at a concentration of 250 $\mu \mathrm{g} /$ disc by the disc diffusion assay method ${ }^{22-24}$ against a number of gram positive and gram negative bacteria and fungi (Table 1), by using kanamycin $(30 \mu \mathrm{g} / \mathrm{disc})$ as reference. Nutrient agar medium (DIFCO) was used in the present study to prepare fresh culture. The discs were then incubated on the plate aerobically at $37^{\circ} \mathrm{C}$ for 24 hours. The zones of inhibition were measured and recorded at the end of the incubation period. Similarly antimicrobial activity of the crude methanol extract and mixed fractions (F34 and 35) from A. lebbek were also determined by the same process (Table 2). The crude methanol extract and caffeine (1) of E. saman were found to produce zone of inhibition of 8 to $25 \mathrm{~mm}$ and 10 to $27 \mathrm{~mm}$, respectively, with prominent activity against Candida albicans with zone of inhibition of 22 and $20 \mathrm{~mm}$, respectively. From Table 1, it is evident that the zone of inhibition for the crude methanol extract was prominent against $E$. coli $(25 \mathrm{~mm}), B$. megaterium $(22 \mathrm{~mm})$ and B. subtilis $(22 \mathrm{~mm})$. From Table 2, the zone of inhibition produced by the crude methanol extract and mixed fractions (F-34 and 35) of A. lebbek were found to be 08 to $14 \mathrm{~mm}$ and 08 to $10 \mathrm{~mm}$ at the concentrations of $500 \mu \mathrm{g} / \mathrm{disc}$ and 250 $\mu \mathrm{g} /$ disc, respectively. The crude methanol extract showed good activity against Salmonella typhi (14 $\mathrm{mm})$, Vibrio parahemolyticus $(14 \mathrm{~mm})$ and Saccharromyces cevevaceae (14 mm).

Following the procedure of Meyer, ${ }^{25}$ the lethality of crude methanol extract to brine shrimp was determined on Artemia salina. For the experiment 2.0 $\mathrm{mg}$ of each of the extract was dissolved in DMSO and serially diluted to get solutions of varying concentrations such as $200,100,50,25,12.50,6.25$, $3.125,1.563,0.781$ and $0.3905 \mu \mathrm{g} / \mathrm{mL}$. In the cytotoxicity screening, vincristine sulfate was used as standard. The results of the brine shrimp lethality testing were obtained after 24 hours of exposure to the samples and the positive control, vincristine sulphate. The $\mathrm{LC}_{50}$ were found to be 0.625 and 1.56 $\mu \mathrm{g} / \mathrm{mL}$ for vincristine sulfate and crude methanol extract of $E$. saman, respectively. The $\mathrm{LC}_{90}$ value was also determined $39 \mu \mathrm{g} / \mathrm{mL}$ for crude methanol extract of E. saman to find the toxicity level of the fractions. In comparison with the positive control (vincristine sulfate) the cytotoxic activity of the crude extract of E. saman was significant. The $\mathrm{LC}_{50}$ of crude methanol extract and mixed fractions (F-34 and 35) from A. lebbek were 3.125 and $1.56 \mu \mathrm{g} / \mathrm{mL}$, respectively. While the $\mathrm{LC}_{90}$ value were found to be 170.0 and $50.0 \mu \mathrm{g} / \mathrm{mL}$, respectively to determine the toxic level of the extracts.

\section{ACKNOWLEDGEMENTS}

The authors are thankful to Analytical Research Division, Bangladesh Council of Scientific and Industrial Research (BCSIR), Dhaka, Bangladesh; Bangadesh National Herberium (BNH) for identifying the plant and Institute of Nutrition and Food Science (INFS), University of Dhaka for supplying microorganisms as pure culture.

\section{REFERENCES}

1. Staples, G.W. and Elevitch, C.R. 2006. Species Profiles for Pacific Island Agroforestry. Permanent Agriculture Resources (PAR), Holualoa, Hawaii. pp. 1-15.

2. Mimaki, Y., Harada, H., Sakuma, C., Haraguchi, M., Yui, S., Kudo, T., Yamazaki, M. and Sashida. 2003. Enterolosaponins A and B, novel triterpene bisdesmosides from Enterolobium contortisiliquum, and evaluation for their macrophage-oriented cytotoxic activity. Bioorg. Med. Chem. Lett. 13, 623-627.

3. Kjaer, A. and Vesterager, E. 1960. Amino Acid Studies. Part III, Synthesis and properties of some isomerides of albizziine. Acta Chemica Scandinavica 14, 961-964.

4. Inouye, S., Shomura, T., Tsuruoka, T., Ogawa, Y., Watanabe, H., Yoshida, J. and Niida, T. 1975. L-beta-(5-Hydroxy-2pyridyl)-alanine and L-beta-(3-Hydroxyureido)-alanine from Streptomyces. Chem. Pharm. Bull. 23, 2669-2677.

5. Buckingham, J., 1996. Dictionary of Natural Products, Chapman and Hall, London, UK, p. 545.

6. Prinsen, J.H. 1986. Potential of Albizia lebbeck as a tropical fodder tree - a review of literature. Tropical Grassland 29, 78-83.

7. Rashid, R.B., R. Chowdhury, Hasan, C.M. and Rashid, M.A. 2003. Constituents of Albizzia lebbek and antibacterial activity of an isolated flavone derivative. Saudi Pharm. J. 11, $52-56$. 
8. Kirtikar, K.R. and B.D. Basu, 1980. Indian Medicinal Plants, Bishen Singh Mahendra Pal Singh, Dehra Dun, India, p. 2793.

9. Orwa, C., Mutua,A., Kindt, R., Jamnadass, R. and Anthony, S. 2009. Agroforestree Database: A Tree Reference and Selection Guide. International Centre for Research in Agroforestry, Nairobi, Kenya, p. 6.

10. Varshney, I.P. 1976. Glycosides and carbohydrates from the members of the family Leguminosae. Univ. Indore Res. J. Sci. 4, 13-22.

11. Pal, B.C., Achari, B., Yoshikawa, K. and Arihara, S. 1995. Saponins from Albizzia lebbek. Phytochemistry 38, 12871291.

12. Deshpande, V.H. and Shastri, R.K. 1977. Phenolics of Albizzia lebbek, A. amara and A. procera. Indian J. Chem. 15, 201-204.

13. Jain, A.S. and Mishra, K.L. 1963. Assay the volatile oil of the flowers of Albizia lebbeck L. Tetrahedron Lett. 1, 19-20.

14. Rayudu, K.H. and Rajadurai, G.F. 1965. Investigation of D catechin in the bark of Albizia lebbeck L. Phytochemistry 113, 258-263.

15. Farooqi, M.I.H. and Kaul, K.N. 1962. Investigation of the chemical composition of the gum of Albizia lebbeck L. trees. J. Sci. Ind. Res. 21, 454-455.

16. Kufuku, U.H. and Huta, L.K. 1934. Analysis the oil of Albizia lebbeck L. Tetrahedron Lett. 1, 15-16.

17. Trease, G.E. and Evans, W.C. 1989. A Text-Book of Pharmacognosy. Baillière Tindall, Alden Press, Oxford, p. 53.
18. Kan, L.S., Borer, P.N., Cheng, D.M. and Ts'o, P.O.P. 1980. ${ }^{1} \mathrm{H}$ and ${ }^{13} \mathrm{C}$-NMR studies on Caffeine and its interaction with nucleic acids. Biopolymers 19, 1641-1654.

19. Dhami, K.S. and Stothers, J.B. 1966. ${ }^{13} \mathrm{C}$ NMR studies: VIII. ${ }^{13} \mathrm{C}$ spectra of some substituted anisoles. Canadian J. Chem. 44, 2855-2866.

20. Birkinshaw, J.H. and Chaplen, P. 1995. Biochemistry of the wood-rotting fungi. 8. Volatile metabolic products of Daedalea juniperina Murr. Biochem. J. 60, 255-261.

21. Sylvie, R., Sophie, B., Thierry, T., Yves, P. and Bessière, J.M. 2002. The anise-like odor of Clitocybe odora, Lentinellus cochleatus and Agaricus essettei. Mycologia 94, 373-376.

22. Zavala, S.M.A., Perez, G.S. and Perez, G.M. 1997. Antimicrobial screening of some medicinal plants. Phytotheraphy Res. 11, 368-371.

23. Murray, P.R., Baron, E.J., Pfallar, M.A., Tenover, F.C. and Yolke, R.H. 1995. Manual of Clinical Microbiology, Washington DC, USA, pp. 214-15.

24. Bauer, A.W., Kirby, W.M.M., Sherries, J.C. and Truck, M. 1966. Antibiotic susceptibility testing by standard single disc diffusion method. Am. J. Clin. Pathol. 45, 426-493.

25. Meyer, B.N., Ferringni, N.R., Puam, J.E., Lacobsen, L.B., Nichols, D.E. and McLaughlin, J.L. 1982. Brine shrimp: a convenient general bioassay for active constituents. Planta Med. 45, 31-32. 